\title{
Cocaine-associated increase of atrial natriuretic peptides: an early predictor of cardiac complications in cocaine users?
}

\author{
Alessandro Casartelli, ${ }^{1,2}$ Lisa Dacome, ${ }^{1}$ Michela Tessari, ${ }^{1}$ Jennifer Pascali, ${ }^{2}$ \\ Federica Bortolotti, ${ }^{2}$ Maria Teresa Trevisan, ${ }^{4}$ Oliviero Bosco, ${ }^{5}$ Patrizia Cristofori, ${ }^{3}$ \\ Franco Tagliaro ${ }^{2}$
}

${ }^{1}$ Toxicology and Pathology Department, Aptuit Medicine Research centre, Verona, Italy ${ }^{2}$ Faculty of Medicine and Surgery, Public Health and Community Medicine Department, University of Verona, Verona, Italy ${ }^{3}$ GlaxoSmithKline PathologySafety Assessment, Ware Herfordshire, UK

${ }^{4}$ Analysis Laboratory, Fracastoro Hospital, Verona, Italy

${ }^{5}$ Servizio Tossicodipendenze (SERT), Verona, Italy

\section{Correspondence to}

Dr Alessandro Casartelli, Toxicology and Pathology Department, Aptuit Medicine Research centre, via Fleming 4 , Verona 37135, Italy; alessandro.casartelli@aptuit.com

Received 18 November 2013 Revised 26 May 2014 Accepted 15 June 2014
CrossMark

To cite: Casartelli $A$ Dacome L, Tessari M, et al. Heart Asia 2014;6:100

107. doi:10.1136/heartasia2013-010482

\begin{abstract}
Objective Cocaine is known to produce lifethreatening cardiovascular complications, and the investigation of the causes of death may be challenging in forensic medicine. The increasing knowledge of the cardiac function biomarkers and the increasing sensitivity of assays provide new tools in monitoring the cardiac life-threatening pathological conditions and in the sudden death investigation in chronic abusers. In this work, cardiac dysfunction was assessed in an animal model by measuring troponin I and natriuretic peptides as biomarkers, and considering other standard endpoints used in preclinical toxicology studies.
\end{abstract}

Methods Lister Hooded rats were treated with cocaine in chronic self-administration studies. Troponin I (cTnl) and atrial natriuretic peptide (ANP) were evaluated at different time points and heart weight and histopathology were assessed at the end of the treatment period. Furthermore, cocaine and its main metabolites were measured in the rat fur to assess rats' cocaine exposure. All the procedures and endpoints considered were designed to allow an easy and complete translation from the laboratory animals to human beings, and the same approach was also adopted with a group of 10 healthy cocaine abuse volunteers with no cardiac pathologies.

Results Cardiac troponin I values were unaffected, and ANP showed an increasing trend with time in all cocainetreated animals considered. Similarly, in the healthy volunteers, no changes were observed in troponin serum levels, whereas the $\mathrm{N}$-terminal brain natriuretic propeptide (NT proBNP) showed variations comparable with the changes observed in rats.

Conclusions In conclusion, natriuretic peptides could represent an early indicator of heart dysfunction liability in chronic cocaine abusers.

\section{INTRODUCTION}

Cocaine, as other psycho-excitatory drugs, is known to produce potentially life-threatening cardiovascular complications. As widely described in the literature, these complications include myocardial ischaemia and necrosis, prothrombotic effects, vasospasms, accelerated coronary atherosclerosis, hypertension, proarrhythmia and a number of electrocardiographic changes. ${ }^{1} 2$ Also, in the Western world as well as in many developing countries, cocaine has been reported by medical examiners as the most frequent cause of drug-related deaths and, after cannabis, the second illicit drug associated with traffic and occupational accidents.
Several scientific papers have been written on this topic giving insights on the patho-physiological mechanism of action, providing descriptions of the cardiological findings and reporting the epidemiological data. However, despite the fairly large body of literature currently available, the mechanisms underlying the cardiovascular adverse effects of cocaine have not been fully understood yet. In general, cocaine is known to increase ventricular contractility, blood pressure and heart rate, leading to an escalating myocardial oxygen demand ${ }^{1} 2$ and to an increased cardiac workload, which per se can be considered, particularly in chronic users, risk factors of cardiac dysfunction. On these grounds, it is easy to hypothesise that cocaine chronic abuse may represent an overlooked background of sudden death in young people. ${ }^{3}$

In this scenario, it is of the highest relevance to better understand the patho-physiological role of the chronic abuse of cocaine on the hearth functions and particularly to identify possible changes of chemical and biochemical parameters to be used as early biomarkers of this subtle but potentially life-threatening pathological condition.

On the other hand, the same parameters could be precious, in forensic cases, for a correct unravelling of the causes of death of cocaine users by integration of the blood cocaine concentrations with the other pathological, toxicological and biochemical data. ${ }^{4-6}$

Thus, the aim of the present study was to verify the ability of the most recent highly sensitive biomarkers of heart overload, failure and damage, such as cardiac troponin I (cTnI) and the atrial natriuretic peptides (ANPs), to reveal at an early stage the cardiovascular pathological effects exerted by cocaine. The study was carried out in a fully controlled animal model, and, although preliminarily, in humans. In particular, cTnI, a well-known marker of myocardial necrosis, was analysed by using a high sensitivity method to highlight the possible occurrence of minor cardiac injuries correlated to cocaine intake, as it has been reported in some other para-physiological stress conditions. ${ }^{7-10}$ In addition, ANP was determined as a recognised indicator of the cardiac overload and failure. ${ }^{11} 12$ The results from the animal studies were then preliminarily verified in a small group of chronic cocaine abusers. In both cases, the individual chronic exposure to cocaine was assessed by determination of this molecule and its major metabolite in the hair. 


\section{STUDY DESIGN}

\section{Preclinical study in rats}

Study design

Five different chronic (up to 12-18 weeks) self-administration studies in Lister Hooded rat were set up. Each animal was previously prepared with a surgical implantation of a catheter in the jugular vein, and trained to push a lever to activate the cocaine self-administration. When rats became addicted and fully trained to the self-administration, they were treated at two different dosing regimens: a low dose regimen (adopted in four of the five studies) included the self-administration in the jugular vein for $3 \mathrm{~h} \backslash$ day of $0.5 \mathrm{mg} \backslash \mathrm{kg}$ of cocaine each infusion, whereas in the high dose the rats were free to self-administer the same amount of cocaine for up to $12 \mathrm{~h} \backslash$ day. Rats followed a controlled diet regimen, in order to standardise the weight gain.

\section{Blood and tissue sample collection}

Blood samples were taken at predose, at the study start and at different time points throughout the study. Blood was obtained by caudal vein venepuncture or by abdominal aorta at terminal kill, and put in Microtainer (BD Medical) without anticoagulant. Blood samples after clotting were centrifuged $5 \mathrm{~min}$ at $3200 \mathrm{rcf}$ and serum obtained was stored at $-80^{\circ} \mathrm{C}$. Animals were not fasted before sampling.

At the end of each study, animals were euthanised by exsanguination in isofluorane deep anaesthesia; blood samples were taken and serum was prepared and stored at $-80^{\circ} \mathrm{C}$. During necropsy session, a macroscopic observation of the abdominal/ thoracic cavity was performed; then, hearts were collected and put in formalin pots. Both heart and brain were weighed.

Rat fur was shaved from a total of 29 rats, after a treatment duration ranging from 28 to 36 days.

\section{Cocaine intake and exposure}

The cocaine intake was estimated on the basis of the number of administrations each animal was able to activate by pressing a lever located inside the cage; at each lever press, the animal received $0.5 \mathrm{mg} / \mathrm{kg}$ of cocaine. From these data, the mean value per day was calculated for all animals, and expressed as $\mathrm{mg} / \mathrm{kg} / \mathrm{day}$.

Furthermore, cocaine exposure was evaluated by measuring cocaine, benzoylecgonine and ecgonine methylester in rat fur by using a model 6850 gas chromatograph coupled to a model 5975C mass spectrometer (Agilent Technologies, Santa Clara, California, USA). ${ }^{13}$ Rat fur samples were washed three times with Tween $20 \%$ and then cut in small fragments. Approximately $50-100 \mathrm{mg}$ were hydrolysed in $0.1 \mathrm{M} \mathrm{HCl}$, overnight at $40^{\circ} \mathrm{C}$. Surnatants were neutralised by adding $100 \mu \mathrm{L} \mathrm{NaOH}$ and $1 \mathrm{~mL}$ of phosphate buffer ( $\mathrm{pH}$ 6.8). Samples were purified by Solid Phase Extraction (Bond Elut Certify, Agilent Technologies, Santa Clara, California, USA). ${ }^{14}$ Samples were taken to dryness at $60^{\circ} \mathrm{C}$ for $1.5 \mathrm{~h}$. Before analysis, samples were reconstituted with $50 \mu \mathrm{L}$ of N-Methyl-N-(trimethylsilyl) trifluoroacetamide (MSTFA, Sigma-Aldrich, St. Louis, Missouri, USA). Specific exposure evaluations for white and black fur were performed to assess the different cocaine's affinity to melanin-rich fur.

\section{Histopathology examination}

Cardiac tissue was selected from hearts collected at necropsy, and all the selected samples were processed by an automated processor (Tissue-Tek VIP 5-Sakura, Torrance, California, USA) and embedded into paraffin wax blocks. From this material, $3-\mu \mathrm{m}$ thin sections were produced using a rotative microtome (Micron HM355S, Haryana, India), stained with H\&E
(Tissue-Tek DRS 2000 Slide Stainer, Medical Equipment Source, LLC, Mars, Pennsylvania, USA), and microscopically examined with a light microscope.

\section{Biomarkers measurement}

Myocardial troponin I (cTnI) was measured on rat serum by using an ultra sensitive immunoassay (Tnl-Ultra, Siemens, Erlangen, Germany) performed on an automated analyser (Advia Centaur CP, Siemens, Erlangen, Germany). A total of 106 samples collected at different time points (from day 21 to day 124) from 25 rats, included in three different selfadministration studies were considered for $\mathrm{cTnI}$ analysis.

The ANP determinations were performed on rat serum samples by using the SPI Bio Rat Atriopeptin enzyme immunoassay (SPI Bio, Montigny Le Bretonneux, France). A total of 121 samples taken from 53 cocaine-treated animals included into five different self-administration studies were selected to be analysed in five different experiments.

\section{Study on cocaine human abusers \\ Study design}

Ten chronic cocaine abusers were selected from the patients of the outpatient clinic on drug addictions of Verona (SERT). The selection was made on the basis of their recent history of cocaine addiction, age and absence of cardiac symptoms. All the subjects provided informed consent to enter the study. All the enrolled subjects were between 22 and 42 years old (average 30.8). Reportedly, they had never suffered from cardiac symptoms nor had past history of medical care due to cardiac affections; furthermore, all the volunteers were constantly monitored on the clinical side, and no evidences of cardiac failure or other health problems were found at the time of the testing.

\section{Sample collection}

From each volunteer, blood and hair were collected. Blood was collected from the forearm cephalic vein into Vacutainer (BD Medical) without anticoagulant for serum. Serum was obtained by centrifugation at $2000 \mathrm{rcf}$ for $10 \mathrm{~min}$, and stored at $-20^{\circ} \mathrm{C}$ until analysed.

\section{Cocaine intake}

In order to estimate (although approximately) the chronic intake and the overall drug exposure, cocaine, benzoylecgonine, ecgonine methylester and cocaethylene were determined in the scalp hair by using the same procedures and instrumentation as for the analysis of the rat fur.

\section{Biomarkers evaluation}

The ultra sensitive troponin $\mathrm{T}$ (cTnT) and the $\mathrm{N}$-terminal brain natriuretic pro-peptide (NT proBNP) were measured in human serum by using a Roche immunochemistry automated analyser (Cobas 8000 modular analyzer, Roche, Rotkreuz, Switzerland).

\section{Data analysis}

In order to reduce the inherent variability of the ANP data measured in the rat studies, two different approaches have been adopted:

- The results obtained in each experiment at the different time points were normalised toward the corresponding predose concentration. The statistical evaluation was carried out using the Student $t$ test for paired data.

- In order to increase the number of observations included in each group undergoing statistical analysis, ANP results 
measured in different experiments were grouped together in four time ranges arbitrarily chosen (predose, day 1-32, day 42-61 and above 80 days of treatment). Each of the three time points was then compared with the predose data using the Student $\mathrm{t}$ test.

Results obtained in human volunteers were not statistically evaluated, due to their limited number.

\section{Ethical statement}

All human samples were collected from volunteers enrolled in an Italian's Public Health structure for a detoxification treatment. Since no changes were made in the treatment programme, but additional analyses on hair and blood samples were performed, only the informed consent by all the participants was requested and obtained.

\section{RESULTS}

\section{Studies in rats}

Because of complications occurred during the study, such as catheter obstruction or infections, a significant number of animals did not conclude the entire cycle of treatment. However, in the present work only the animals which regularly assumed cocaine throughout the study were included and considered.

\section{Cocaine administration}

Animals were left to self-administer cocaine for $3 \mathrm{~h} /$ day (low dose group) and for $12 \mathrm{~h} /$ day (high dose group). In the low dose group, the average dose administered was $15.4 \mathrm{mg} / \mathrm{kg} / \mathrm{day}$, whereas animals treated at the high dose received $112.6 \mathrm{mg} / \mathrm{kg} /$ day (average dose). The estimated doses administered to each rat for the low and high dose regimen are reported in table 1.

In a subgroup of 29 animals treated with cocaine for 28 36 days, the exposure of the individual animals was also estimated by the analysis of cocaine and benzoylecgonine in the rat fur. The results are reported in tables 2 and 3.

As shown in table 2, black fur showed a higher affinity for cocaine, as expected from the literature data. Some inconsistencies in the results from hair analysis were probably due to fur contamination with urine.

Fur hair analysis for rats treated with cocaine for 32 days at higher doses-112.6 mg/kg/day (average) — are reported in table 3. In this case, only white fur hair was collected.

\section{Organ weight and histopathology}

Heart and brain were collected where possible from animals chronically treated. Tissues were processed in paraffin wax and stored for future evaluations. At necropsy, no apparent pathological findings at the macroscopic observations were registered. A summary of the measured heart weights is reported in table 4 .

Heart weight increments were seen in isolated animals, with no group trend. One animal treated at $112.6 \mathrm{mg} / \mathrm{kg} /$ day showed the highest increase in terms of heart weight relative to body weight. A correlation trend between the heart weight and ANP values was seen, even if not fully consistent for all animals considered. No statistical significance was however found between different treatment groups for organ weights or between ANP and organ weight values.

Microscopic examinations of the heart from both low $(15.4 \mathrm{mg} / \mathrm{kg} /$ day $)$ and high $(112.6 \mathrm{mg} / \mathrm{kg} /$ day $)$ doses did not reveal any morphological alteration in any of the animals examined.
Table 1 Estimated doses administered to Lister Hooded rats

\begin{tabular}{|c|c|c|c|}
\hline \multicolumn{2}{|c|}{ Low dose treatment regimen } & \multicolumn{2}{|c|}{ High dose treatment regimen } \\
\hline Rat number & $\begin{array}{l}\text { Estimated dose } \\
\text { (mg/kg/day) }\end{array}$ & Rat number & $\begin{array}{l}\text { Estimated dose } \\
\text { (mg/kg/day) }\end{array}$ \\
\hline H206 & 13.17 & B426 & 106.80 \\
\hline 1206 & 16.00 & D426 & 102.17 \\
\hline K206 & 11.16 & H426 & 100.15 \\
\hline M206 & 18.33 & K426 & 134.35 \\
\hline R206 & 18.16 & L426 & 136.76 \\
\hline T206 & 22.50 & M426 & 135.26 \\
\hline V206 & NM & N426 & 112.27 \\
\hline W206 & 16.17 & 0426 & 118.75 \\
\hline U351 & 20.24 & R426 & 129.37 \\
\hline V351 & 27.98 & S426 & 114.60 \\
\hline AC351 & 14.13 & V426 & 105.92 \\
\hline V654 & NM & W426 & 81.00 \\
\hline W654 & NM & Y426 & 112.15 \\
\hline K207 & 18.90 & AA426 & 112.13 \\
\hline P214 & 13.08 & AC426 & 115.61 \\
\hline A233 & 12.32 & C426 & 161.05 \\
\hline B233 & 11.07 & 1426 & 65.43 \\
\hline C233 & 9.57 & U426 & 82.32 \\
\hline D233 & 13.70 & & \\
\hline D250 & 14.50 & & \\
\hline F250 & 12.43 & & \\
\hline F233 & NM & & \\
\hline A250 & 11.10 & & \\
\hline E250 & NM & & \\
\hline E233 & 22.50 & & \\
\hline 1250 & 16.13 & & \\
\hline C250 & 14.58 & & \\
\hline L250 & NM & & \\
\hline H250 & NM & & \\
\hline$J 250$ & NM & & \\
\hline K250 & NM & & \\
\hline B250 & 16.75 & & \\
\hline G250 & 12.42 & & \\
\hline M184 & 11.92 & & \\
\hline R184 & 10.42 & & \\
\hline Mean & 15.36 & Mean & 112.56 \\
\hline SD & 4.40 & SD & 22.66 \\
\hline
\end{tabular}

\section{Biomarker evaluation}

In line with the lack of histopathological findings, no significant increases in troponin I (cTnI) were found in all animals examined from both low and high doses.

ANP data are summarised in figure 1 .

The diagram in figure 1 suggests a time dependent trend to increase for ANP. Due to the inter assay variability, the results were not grouped together; however, considering every single experiment (measured in the same assay), a constant increasing trend was demonstrated in all the experiments performed. All experiments except number 5 were performed at low $(15.4 \mathrm{mg} /$ $\mathrm{kg} /$ day mean value) dose; the experiment number 5 was the only performed at higher dose $(112.6 \mathrm{mg} / \mathrm{kg} / \mathrm{day}$ mean value), but a single time point (day 31) for all animals is the only available.

The same results shown in figure 1 are reported also in figure 2, where the statistical analysis was performed in a limited number of 
Table 2 Exposure data from rats treated at low dose treatment regimen. Results obtained from black and white fur are reported separately

\begin{tabular}{|c|c|c|c|c|c|}
\hline \multirow[b]{2}{*}{$\begin{array}{l}\text { Rat } \\
\text { number }\end{array}$} & \multirow{2}{*}{$\begin{array}{l}\text { Dose* } \\
\text { mg/kg/day } \\
\text { (mean) }\end{array}$} & \multicolumn{2}{|c|}{$\begin{array}{l}\text { Exposure } \\
\text { (black fur) }\end{array}$} & \multicolumn{2}{|c|}{$\begin{array}{l}\text { Exposure } \\
\text { (white fur) }\end{array}$} \\
\hline & & $\begin{array}{l}\text { Cocaine } \\
\text { (ng/mg) }\end{array}$ & $\begin{array}{l}\text { BE } \\
\text { (ng/mg) }\end{array}$ & $\begin{array}{l}\text { Cocaine } \\
\text { (ng/mg) }\end{array}$ & $\begin{array}{l}\text { BE } \\
\text { (ng/mg) }\end{array}$ \\
\hline W654 & 20.66 & 4.008 & 1.086 & 0.231 & 0.508 \\
\hline V654 & 26.84 & 0.474 & 0.481 & Out & Out \\
\hline K207 & 18.90 & 0.982 & 0.375 & 0.218 & 0.360 \\
\hline P214 & 13.08 & 0.534 & 0.287 & 0.290 & 0.334 \\
\hline R206 & 18.16 & 3.446 & 0.951 & 0.160 & 0.313 \\
\hline T206 & 22.50 & 0.833 & 0.437 & 0.187 & 0.480 \\
\hline K206 & 11.16 & 1.280 & 0.380 & 0.108 & 0.259 \\
\hline M206 & 18.33 & 0.648 & 0.303 & 0.152 & 0.305 \\
\hline $\mathrm{H} 206$ & 13.17 & 1.139 & 0.398 & 0.129 & 0.671 \\
\hline 1206 & 16.00 & 0.645 & 0.232 & 0.172 & 0.954 \\
\hline W206 & 16.17 & Out & Out & 0.218 & 0.393 \\
\hline Mean & 17.72 & 1.399 & 0.493 & 0.186 & 0.458 \\
\hline SD & 4.55 & 1.261 & 0.288 & 0.054 & 0.213 \\
\hline
\end{tabular}

Ecgonine methylester is not reported, as not measurable in most of the samples. ${ }^{*}$ Assuming $300 \mathrm{~g}$ of rat body weight.

$\mathrm{BE}$, benzoylecgonine; Out, outlier.

experiments with adequate numerosity: the last time points of each experiment were statistically different from the respective predose value in all the three experiments reported. Furthermore, the statistical analysis was repeated after having pooled together the results in four time point ranges in order to increase the data number (figure 3).

Table 3 Exposure data from rats treated at high dose treatment regimen

\begin{tabular}{|c|c|c|c|c|}
\hline \multirow[b]{2}{*}{$\begin{array}{l}\text { Rat } \\
\text { number }\end{array}$} & \multirow{2}{*}{$\begin{array}{l}\text { Dose* } \\
\text { mg/kg/day } \\
\text { (mean) }\end{array}$} & \multicolumn{2}{|c|}{ Exposure (white fur) } & \multirow[b]{2}{*}{$\begin{array}{l}\text { EME } \\
\text { (ng/mg) }\end{array}$} \\
\hline & & $\begin{array}{l}\text { Cocaine } \\
\text { (ng/mg) }\end{array}$ & $\begin{array}{l}\text { BE } \\
\text { (ng/mg) }\end{array}$ & \\
\hline M426 & 135.26 & 2.29 & 0.87 & 0.65 \\
\hline C426 & 161.05 & 2.93 & 1.22 & 1.26 \\
\hline 1426 & 65.43 & 70.31 & 10.62 & 1.72 \\
\hline U426 & 82.32 & 2.82 & 1.32 & 0.60 \\
\hline 0426 & 118.75 & 86.62 & 53.93 & 2.59 \\
\hline S426 & 114.60 & 96.04 & 21.92 & 2.65 \\
\hline R426 & 129.37 & 72.56 & 9.01 & 1.46 \\
\hline AA426 & 112.13 & 4.93 & 1.08 & 0.88 \\
\hline V426 & 105.92 & 1.93 & 1.27 & 0.82 \\
\hline W426 & 81.00 & 2.83 & 1.09 & 0.79 \\
\hline AC426 & 115.61 & 2.97 & 0.98 & 0.57 \\
\hline Y426 & 112.15 & 2.85 & 1.28 & 0.90 \\
\hline H426 & 100.15 & 28.35 & 4.63 & 2.07 \\
\hline B426 & 106.80 & 4.06 & 2.07 & 0.96 \\
\hline L426 & 136.76 & 1.99 & 0.91 & 0.64 \\
\hline D426 & 102.17 & 8.33 & 2.73 & 1.07 \\
\hline N426 & 112.27 & 9.56 & 3.09 & 0.98 \\
\hline K426 & 134.35 & 3.15 & 0.69 & NM \\
\hline Mean & 112.56 & 22.47 & 6.59 & 1.21 \\
\hline SD & 22.66 & 33.35 & 12.96 & 0.67 \\
\hline
\end{tabular}

Finally, results obtained in the high dose experiment (experiment number 5, figure 4) were compared with a group of control rats, treated with saline for a longer period and approximately 2 months older: also in this case, the younger cocainetreated rats showed significantly higher ANP values than the ones collected in elder control rats.

In conclusion, it was demonstrated that ANP values progressively increase along time in all the cocaine-treated rats. The relationship between ANP values and the cocaine dose or exposure are instead less clear, maybe due to the limited numerosity and/or inter-individual variability.

\section{Cocaine human abusers study}

Cocaine intake

Six out of 10 volunteers referred to have used cocaine within 5 days before the hair sampling. All but one the volunteers showed measurable concentrations of cocaine and benzoylecgonine in the scalp hair, but only three showed a measurable concentration of cocaethylene.

Results are summarised in table 5 .

\section{Biomarker evaluation}

As already observed in rats, no increases in cardiac troponin $\mathrm{T}$ $(\mathrm{cTnT})$ values were observed in humans. All values except one were below the quantification limit, and the only one measurable was within the very low.

NT proBNP showed concentrations ranging from 5.32 to $111.6 \mathrm{pg} / \mathrm{mL}$. All these values were within the normal range, as defined on the basis of the laboratory's historical data; however, some of them are close to the upper limit reference of $125 \mathrm{pg} /$ $\mathrm{mL}$ (table 5). This is substantially in agreement with the clinical data reporting no cardiac insufficiency in any of the volunteers; however, three out of four volunteers who refer to have massive or regular cocaine assumption had also the three highest values of NT proBNP recorded (table 5), suggesting another possible correlation between natriuretic peptide increases and cocaine consumption.

The comparison between NT proBNP concentrations in plasma and the cocaine and benzoylecgonine levels measured in the hair, when subject No. 6 is excluded as an outlier, showed statistical correlation, with coefficient of 0.82 and 0.88 for cocaine and benzoylecgonine, respectively (figure 5).

\section{DISCUSSION AND CONCLUSIONS}

In the present study, the early cardiovascular effects of cocaine in chronically treated rats were investigated by studying both structural and functional early cardiac changes in an animal model under fully controlled experimental conditions. Cocaine-induced cardiovascular changes have been already observed and investigated in rats: ${ }^{15-18}$ the response to cocaine in terms of dependence and cardiovascular changes as well as the cholinesterase activity pattern (representing the primary mechanism of cocaine metabolism to less active compounds) seem to be comparable in humans and rats. ${ }^{12}{ }^{18}$ In particular, rats were described to have cardiovascular changes comparable with those described in humans. Decrease in cardiac output and heart rate, and increase in systemic vascular resistance were described in rats after repeated treatments with cocaine at $5 \mathrm{mg} / \mathrm{kg}$ intravenous. ${ }^{18}$ On these grounds, rats can be proposed as a suitable model to investigate the cocaine-induced cardiovascular changes occurring in humans.

Although several reports are already available in literature describing the cardiovascular alterations induced by cocaine, ${ }^{1-3}$ to the best of our knowledge, no sound evidence is reported on 
Table 4 Summary of heart weight data

\begin{tabular}{|c|c|c|c|c|c|c|c|c|}
\hline Rat code & $\begin{array}{l}\text { Treatment duration } \\
\text { (self-administration) }\end{array}$ & $\begin{array}{l}\text { Cocaine estimated } \\
\text { dose (mg/kg/day) }\end{array}$ & $\begin{array}{l}\text { Body } \\
\text { weight (g) }\end{array}$ & $\begin{array}{l}\text { Heart } \\
\text { weight }(g)\end{array}$ & $\begin{array}{l}\text { Brain } \\
\text { weight }\end{array}$ & $\begin{array}{l}\text { Heart to } \\
\text { body ratio }\end{array}$ & $\begin{array}{l}\text { Heart to } \\
\text { brain ratio }\end{array}$ & $\begin{array}{l}\text { ANP } \\
(\mathrm{pg} / \mathrm{mL})\end{array}$ \\
\hline M184 & 4 months & 15.4 & 320 & 1.178 & NM & 0.368 & - & 9101.50 \\
\hline R184 & 4 months & 15.4 & 305 & 1.081 & NM & 0.354 & - & 11853.38 \\
\hline A233 & 3 months & 15.4 & 360 & 1.085 & NM & 0.301 & - & 10175.46 \\
\hline B233 & 3 months & 15.4 & 320 & 1.095 & NM & 0.342 & - & 10748.12 \\
\hline C233 & 3 months & 15.4 & 348 & 1.073 & NM & 0.308 & - & 6231.20 \\
\hline D233 & 3 months & 15.4 & 335 & 1.260 & NM & 0.376 & - & 19779.27 \\
\hline A250 & 3 months & 15.4 & 340 & 1.095 & NM & 0.322 & - & NM \\
\hline D250 & 3 months & 15.4 & 360 & 1.050 & NM & 0.292 & - & 5046.99 \\
\hline F250 & 3 months & 15.4 & 355 & 1.004 & NM & 0.283 & - & 4238.72 \\
\hline 1184 & 4 months & 0 (Saline control) & 300 & 1.086 & & 0.362 & & NM \\
\hline V654 & 35 days & 15.4 & NM & 0.957 & NM & - & - & NM \\
\hline W654 & 35 days & 15.4 & NM & 0.913 & NM & - & - & NM \\
\hline K207 & 35 days & 15.4 & NM & 0.937 & NM & - & - & NM \\
\hline P214 & 35 days & 15.4 & NM & 0.966 & NM & - & - & NM \\
\hline A426 & 31 days & 0 (Saline control) & 318 & 0.930 & 1.66 & 0.292 & 56.02 & 6386.06 \\
\hline C426 & 2 weeks & 112.6 & 315 & 1.080 & 1.75 & 0.343 & 61.71 & 18800.68 \\
\hline G426 & 31 days & 0 (Saline control) & 327 & 0.930 & 1.76 & 0.284 & 52.84 & 7243.34 \\
\hline 1426 & 2 weeks & 112.6 & 249 & 0.880 & 1.71 & 0.353 & 51.46 & 17559.12 \\
\hline L426 & 31 days & 112.6 & 312 & 0.940 & 1.66 & 0.301 & 56.63 & 6609.90 \\
\hline M426 & 31 days & 112.6 & 288 & 1.230 & 1.5 & 0.427 & 82.00 & 6151.69 \\
\hline 0426 & 31 days & 112.6 & 326 & 0.960 & 1.7 & 0.294 & 56.47 & 6997.02 \\
\hline U426 & 2 weeks & 112.6 & 302 & 1.100 & 1.63 & 0.364 & 67.48 & 25211.15 \\
\hline V426 & 31 days & 112.6 & 307 & 0.920 & 1.77 & 0.300 & 51.98 & 7186.62 \\
\hline \multicolumn{3}{|c|}{ Mean values per dose: $0 \mathrm{mg} / \mathrm{kg} /$ day } & 315.0 & 0.982 & 1.710 & 0.313 & 54.433 & 6814.70 \\
\hline \multicolumn{3}{|c|}{$15.4 \mathrm{mg} / \mathrm{kg} /$ day } & 338.1 & 1.053 & & 0.327 & & 9646.83 \\
\hline \multicolumn{3}{|c|}{$112.6 \mathrm{mg} / \mathrm{kg} /$ day } & 299.9 & 1.016 & 1.674 & 0.340 & 61.105 & 12645.17 \\
\hline
\end{tabular}

A comparison with treatment type, dose and ANP values is also included. A colour code was associated with the estimated dose: white for saline controls, light grey for low dose and dark grey for high dose.

ANP, atrial natriuretic peptide; NM, not measured.

the application of sensitive and non-invasive biomarkers of early cardiac pathological changes in a controlled animal model study design. On the other hand, this information could be of the highest importance for a possible application of these

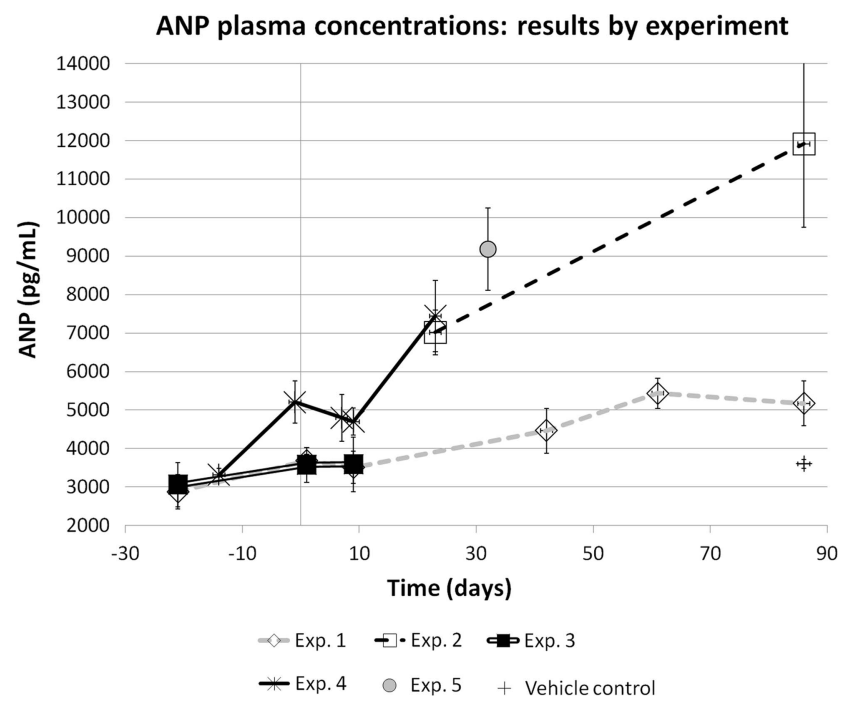

Figure 1 Atrial natriuretic peptide (ANP) values by time in chronic cocaine-treated rats (mean values $\pm S E M)$. To minimise inter assay variability, data are presented by experiment. The first day of treatment is day 1 . biomarkers as early cardiac prognostic parameters in 'healthy' cocaine chronic users.

The present study was focused on two biomarkers, that is, troponin and natriuretic peptides (ANP, brain natriuretic peptide (BNP)), which are known to be very sensitive tools for the identification of cardiac overload/failure and damage. ${ }^{19-24}$ In

\section{ANP plasma concentrations in rat - results by experiment with statistics}

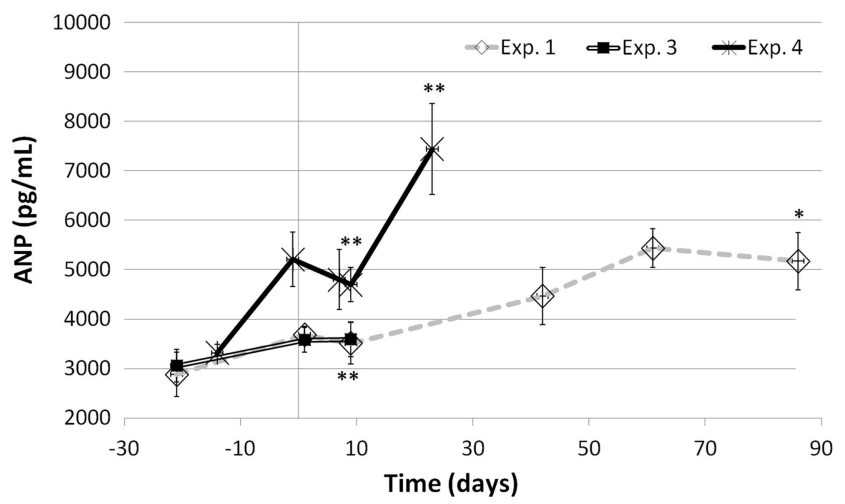

Figure 2 Atrial natriuretic peptide (ANP) values by time in chronic cocaine-treated rats (mean values \pm SEM). Statistical evaluation of results obtained in three experiments (Student $t$ paired analysis vs the predose mean value): ${ }^{*}=p<0.05 ;{ }^{* *}=p<0.01$. The first day of treatment is day 1 . 


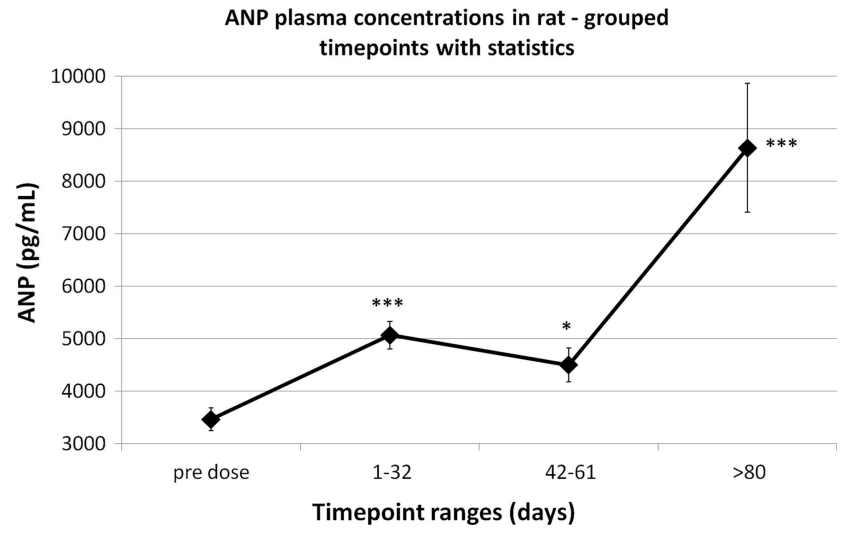

Figure 3 Overall atrial natriuretic peptide (ANP) changes in chronic cocaine-treated rats (mean values \pm SEM). Time points have been grouped together to obtain four time point ranges (Student $t$ test vs the predose mean value): ${ }^{*}=p<0.05 ;{ }^{* *}=p<0.001$. The first day of treatment is day 1 .

particular, troponin was described to increase, although slightly, in some physiological conditions such as athletic performances. ${ }^{7-10}$ Similar increases were also described to be prognostic of cardiac damage and necrosis in some preclinical toxicology works, showing slight changes even before any histopathological evidence of cardiomiocyte necrosis. ${ }^{19}$ A higher sensitivity of troponin analysis than histopathology was also confirmed in measuring focal cardiac necrosis, as reported by several works on preclinical species. ${ }^{10} 2122$ All these pieces of evidence have made troponin (namely, the high sensitive troponin $\mathrm{I}$ or $\mathrm{T}$ ) a first choice biomarker for the detection of cardiac damage at its very beginning.

On the other hand, the natriuretic peptides such as ANP or BNP provide more 'functional' indications, based on cardiac myofibre stretch and highlighting heart workload. In more detail, natriuretic peptides are powerful vasodilators, and involved in the homeostatic control of body water, sodium, potassium and fat (adipose tissue) in response to atrial/ventricular distension and stretching of the vessel walls; these features make the natriuretic peptides a promising tool to monitor the cardiac changes following chronic cocaine treatment. The ANPs are often measured to monitor the asymptomatic or symptomatic left ventricular dysfunction, with a prognostic value in the

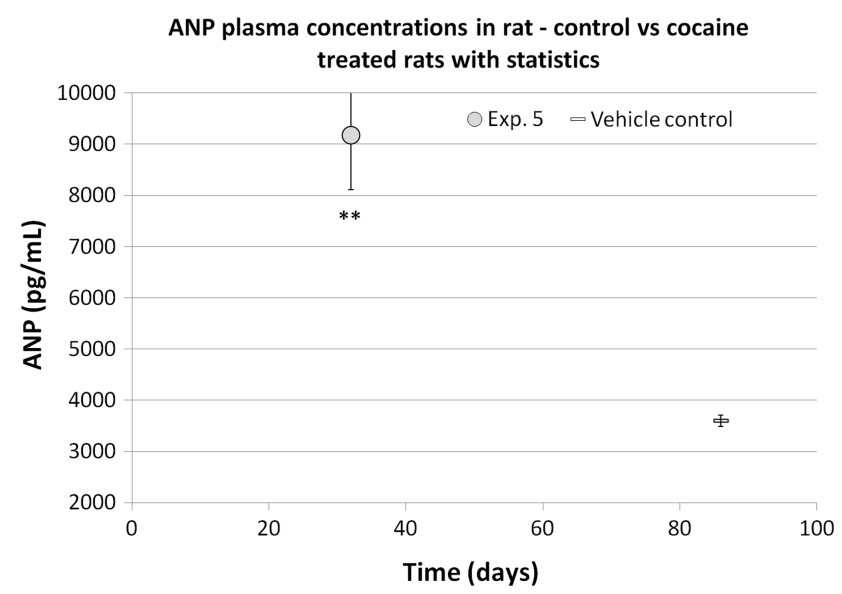

Figure 4 Atrial natriuretic peptide (ANP) changes in chronic cocaine-treated rats compared with elder control rats (mean values \pm SEM). Student $t$ test versus the predose mean value: ${ }^{* *}=p<0.01$. diagnosis and follow-up of acute congestive heart failure. Furthermore, BNP and proBNP have shown diagnostic/prognostic value also in some preclinical toxicology studies, showing changes before any functional or structural evidence of heart damage. ${ }^{19}$

In the present study, the cocaine cardiac effects were monitored in healthy rats by evaluating troponin $\mathrm{I}(\mathrm{cTnI})$ and the ANPs as biomarkers. The research was also completed with histopathological evaluations of the rat heart and with the assessment of cocaine intake by analysing cocaine and its major metabolite (benzoylecgonine) in the rat fur. The results proved that all rats were exposed to cocaine, and concentrations in the low dose group were comparable with the ones normally found in chronic/moderate users. Furthermore, as expected, black fur showed higher cocaine and metabolite content than white fur due to the differences in the melanin content. Rats treated at higher doses $(112.6 \mathrm{mg} / \mathrm{kg} /$ day mean value) showed higher concentrations in fur. On this basis, the use of hair analysis to monitor exposure to cocaine, widely used in humans, could be extended also to rats.

Neither significant cTnI increases nor morphological alterations, particularly in rat heart, were observed after chronic ( $\sim 4$ months) low dose $(15.4 \mathrm{mg} / \mathrm{kg} /$ day mean value) treatment and also after 1 month of high dose $(112.6 \mathrm{mg} / \mathrm{kg} /$ day mean value) cocaine administration.

When functional parameters are considered, ANP showed a time-related trend to increase in all the experiments and at both doses. Although ANP changes have already been reported in literature after cocaine administration ${ }^{11} 15$ associated with changes in cardiovascular parameters (cardiac output, heart rate and systemic vascular resistance), ${ }^{11} 1617$ the present study is, to the best of our knowledge, the first reporting a long term treatment.

On the basis of the results above discussed, the study was also successfully extended to humans chronically abusing cocaine. Troponin $\mathrm{T}$ (as a substitute biomarker for cTnI) and NT proBNP (as a substitute for ANP) were measured in a small number of 'healthy' cocaine abusers. In agreement with the data obtained in animals, troponin $\mathrm{T}$ was unaffected in all subjects. These data look consistent with the reports from Aquaro et al, ${ }^{25}$ in which however other exams such as echocardiography, ECG and cardiovascular magnetic resonance confirmed a high prevalence of cardiac impairment/damage in asymptomatic cocaine addicts.

On the contrary, NT proBNP showed in several cases concentrations close to the upper limit of the normal range, when evaluated on the basis of the laboratory's reference data (due to the limited number of cases, no statistical analysis was performed). However, it must be stressed that the natriuretic peptides concentrations are strongly age dependent and for this reason the typical reference concentration ranges of clinical interest are established on the basis of populations older than the subjects enrolled in the present study.

Consequently, the results from the cocaine users should be better compared with the reference values for the healthy population of matching age. Unfortunately, few papers reporting the NT proBNP concentrations in healthy young subjects are available. According to McDonagh et al, ${ }^{26}$ in 549 normal subjects aged $<40$ years the median for the NT proBNP values were below $20 \mathrm{pg} / \mathrm{mL}$. In the present study, nine out of the $10 \mathrm{sub}$ jects evaluated showed NT proBNP concentrations higher than the median reported by McDonagh et al. ${ }^{26}$

A further piece of evidence in favour of a cocaine-induced increase of natriuretic pepetides in chronic users of this drug is given by an intriguing correlation between an objective indicator 
Table 5 Overall comparison of chronic cocaine abusers' data

\begin{tabular}{|c|c|c|c|c|c|c|c|c|c|c|c|}
\hline Code & Age & $\begin{array}{l}\text { Cardiac } \\
\text { pathologies }\end{array}$ & $\begin{array}{l}\text { Abused } \\
\text { drugs }\end{array}$ & Frequency & $\begin{array}{l}\text { Alcohol } \\
\text { assumption }\end{array}$ & $\begin{array}{l}\text { cTnT } \\
\text { (pg/mL) }\end{array}$ & $\begin{array}{l}\text { NT } \\
\text { proBNP } \\
\text { (pg/mL) }\end{array}$ & $\begin{array}{l}\text { Cocaine } \\
\text { (ng/mg) }\end{array}$ & $\begin{array}{l}\text { Benzoyl } \\
\text { ecgonine } \\
\text { (ng/mg) }\end{array}$ & $\begin{array}{l}\text { Cocaethylene } \\
\text { (ng/mg) }\end{array}$ & $\begin{array}{l}\text { Ecgonine } \\
\text { methylester } \\
\text { (ng/mg) }\end{array}$ \\
\hline 1 & 29 & None & Cocaine & $\begin{array}{l}\text { Occasional since } \\
4 / 5 \text { months }\end{array}$ & Y & $<$ LLoQ & 67.2 & 8.70 & 12.70 & NM & 5.80 \\
\hline 2 & 32 & $\begin{array}{l}\text { Endocarditis } \\
3 \text { years ago }\end{array}$ & $\begin{array}{l}\text { Cocaine } \\
\text { and THC }\end{array}$ & Regular/massive & Y & $<$ LLoQ & 81.7 & 6.40 & 7.90 & 7.00 & 1.10 \\
\hline 3 & 28 & None & $\begin{array}{l}\text { Cocaine } \\
\text { and heroin }\end{array}$ & Massive & Y & $<$ LLoQ & 111.6 & 9.20 & 11.80 & NM & 5.60 \\
\hline 4 & 42 & None & Cocaine & Regular & Y & $<$ LLoQ & 27.6 & 0.99 & 3.65 & NM & 0.67 \\
\hline 5 & 25 & None & $\begin{array}{l}\text { Cocaine } \\
\text { and heroin }\end{array}$ & $\begin{array}{l}\text { Regular (heroin)/ } \\
\text { occasional (cocaine) }\end{array}$ & Y & $<$ LLoQ & 36.2 & 0.96 & 4.50 & NM & NM \\
\hline 6 & 37 & None & Cocaine & Occasional & $\mathrm{N}$ & 3.76 & 24.0 & 17.00 & 22.00 & NM & 5.30 \\
\hline 7 & 41 & None & $\begin{array}{l}\text { Cocaine } \\
\text { and heroin }\end{array}$ & $\begin{array}{l}\text { Regular (cocaine)/ } \\
\text { occasional (heroin) }\end{array}$ & Y (always) & $<$ LLoQ & 102.2 & 4.10 & 8.50 & 3.10 & 2.10 \\
\hline 8 & 25 & None & $\begin{array}{l}\text { Cocaine } \\
\text { and heroin }\end{array}$ & $\begin{array}{l}\text { Massive (heroin)/ } \\
\text { occasional (cocaine) }\end{array}$ & N & $<$ LLoQ & 81.0 & \multicolumn{4}{|c|}{ NM (morphine, codeine and methadon) } \\
\hline 9 & 22 & None & $\begin{array}{l}\text { Cocaine } \\
\text { and heroin }\end{array}$ & Occasional (both) & Y & $<$ LLoQ & 33.8 & 0.80 & 0.30 & 0.50 & NM \\
\hline 10 & 27 & None & $\begin{array}{l}\text { Cocaine } \\
\text { and heroin }\end{array}$ & Occasional (both) & Y & $<$ LLoQ & 5.3 & 0.07 & 0.20 & NM & NM \\
\hline
\end{tabular}

LLoQ, low limit of quantification; NM, not measurable; THC, tetra hydro cannabinol.

of chronic cocaine intake, such as the concentration in hair of the parent drug or its major metabolite, and the NT proBNP concentrations in plasma. This correlation suggests that the overall exposure to cocaine, measured in the hair by means of progressive accumulation of the drug along time, could potentially be related to an increase of the natriuretic peptides in serum, in substantial agreement with the trend observed in rats.

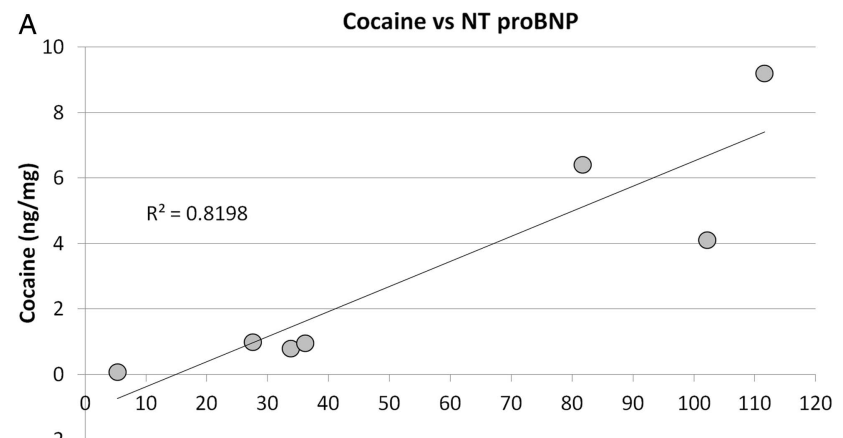

NT proBNP $(\mathrm{pg} / \mathrm{mL})$

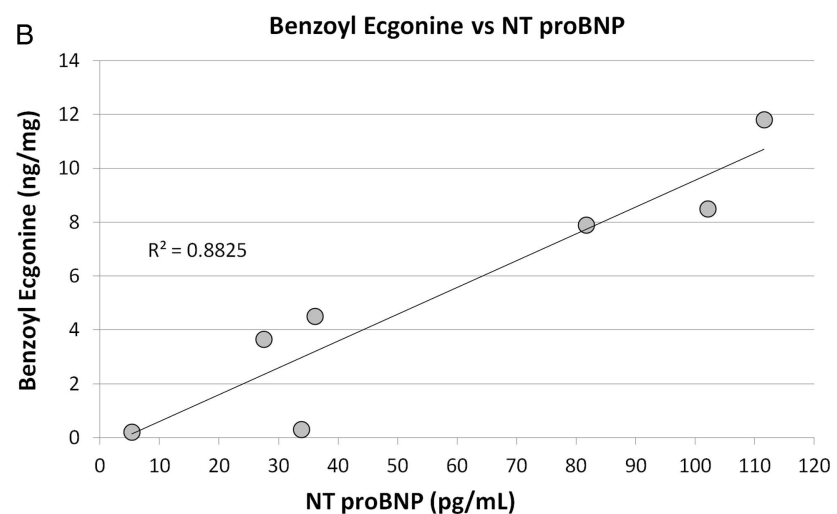

Figure 5 Correlation between NT proBNP values and cocaine/ benzoylecgonine levels measured in the cocaine abusers' hair.
In this scenario, if the same hypothesis proposed for rats can be formulated also in humans, we could assume that monitoring natriuretic peptides is a precious tool to reveal the onset and the progression of the cardiac overload caused by the cocaine chronic intake. This condition may represent the prerequisite for an increased risk of cardiac pathology, which only later can become symptomatic.

In conclusion, in the present study, although tentatively, the natriuretic peptides could be proposed as biomarkers for monitoring the cardiac/cardiovascular risk in 'healthy' cocaine abusers. Eventually, cocaine-alcohol coadministration is another important condition which was not investigated in the present work, but deserves further studies, taking into account the direct cardiotoxicity of ethanol, and considering the reports on a powerful effect on the cardiac function of the product of cocaine and alcohol simultaneous intake, such as cocaethylene. $^{27} 28$

Contributors AC planned and managed the studies, evaluated and discussed the results obtained and wrote this manuscript. LD and MT managed and conducted the rat in vivo phases. JP managed and conducted the hair's analysis for cocaine and metabolite detection and quantification. MTT managed the cardiac markers analysis of human volunteers. OB managed the volunteers' enrolment and sampling procedures. PC supervised the overall work and evaluated the histopathology findings in the rat tissues. FT, FB and PC were responsible for the overall manuscript content as guarantors.

Competing interests None.

Provenance and peer review Not commissioned; externally peer reviewed.

\section{REFERENCES}

Afonso L, Mohammad T, Thatai D. Crack whips the heart: a review of the cardiovascular toxicity of cocaine. Am J Cardiol 2007;100:1040-3.

2 Lange RA, Hillis LD. Cardiovascular complications of cocaine use. N Engl J Med 2001;345:351-8.

3 Bertol E, Trignano C, Di Milia MG, et al. Cocaine-related deaths: an enigma still under investigation. Forensic Sci Int 2008;176:121-3.

4 Karch SB, Stephens BS. When is cocaine the cause of death? Am J Forensic Med Pathol 1991;12:1-2

5 Kintz P. Value of hair in postmortem toxicology. Forensic Sci Int 2004;142:127-34.

6 Drummer $\mathrm{OH}$. Postmortem toxicology of drugs of abuse. Forensic Sci Int 2004;142:101-13. 
7 Shave R, George K, Gaze D. The influence of exercise upon cardiac biomarkers: a practical guide for clinicians and scientists. Curr Med Chem 2007;14:1427-36.

8 Knuepfer M, Branch CA, Mueller PJ, et al. Stress and cocaine elicit similar cardiac output responses in individual rats. Am J Physiol 1993;265:H779-82.

9 Rifai N, Douglas PS, O'Toole M, et al. Cardiac troponin T and I, electrocardiographic wall motion analyses, and ejection fractions in athletes participating in the hawaii ironman triathlon. Am J Cardiol 1999;83:1085-9.

10 Fortescue EB, Shin AY, Greenes DS, et al. Cardiac troponin increases among runners in the boston marathon. Ann Emerg Med 2007;49:137-43.

11 Mahalakaarto J, Ruskoaho H, Huttunen $\mathrm{P}$, et al. Norcocaine is a potent modulator of haemodynamic responses, plasma catecholamines and cardiac hormone release in conscious rats. Toxicol 1998:128:101-11.

12 Knuepfer M, Gan Q. Role of cholinergic receptors and cholinesterase activity in hemodynamic responses to cocaine in conscious rats. Am J Physiol 1999:276:R103-12.

13 Montagna M, Stramesi C, Vignali C, et al. Simultaneous hair testing for opiates, cocaine, and metabolites by GC-MS: a survey of applicants for driving licences with history of drug use. Forensic Sci Int 2000;107:157-67.

14 Tagliaro F, Valentini $\mathrm{R}$, Manetto $\mathrm{G}$, et al. Hair analysis by using radioimmunoassay, high-performance liquid chromatography and capillary electrophoresis to investigate chronic exposure to heroin, cocaine and/or ecstasy in applicants for driving licences. Forensic Sci Int 2000;107:121-8

15 Pelkonen $\mathrm{M}$, Luodonpaa $\mathrm{M}$, Vuolteenaho 0 , et al. Cocaine increases circulating levels of atrial natriuretic peptide and pro atrial natriuretic peptide $\mathrm{N}$-terminal fragment in conscious rats. Eur J Pharmacol 1996;304:55-62.

16 Besse S, Assayag P, Latour C, et al. Molecular characteristics of cocaine-induced cardiomyopathy in rats. Eur J Pharmacol 1997;338:123-9.

17 Knuepfer M, Branch CA, Gan Q, et al. Cocaine-induced myocardial ultrastructural alterations and cardiac output responses in rats. Exp Mol Pathol 1993;59:155-68.
18 Knuepfer M, Mueller PJ. Review of evidence for a novel model of cocaine induced cardiovascular toxicity. Pharmacol Biochem Be 1999;63:489-500.

19 Casartelli A, Lanzoni A, Comelli $\mathrm{R}$, et al. A novel and integrated approach for the identification and characterisation of drug induced cardiac toxicity in the dog. Toxicol Pathol 2011:39:361-71.

20 O'Brien PJ, Smith DEC, Knechtel TJ, et al. Cardiac troponin I is a sensitive, specific biomarker of cardiac injury in laboratory animals. Lab Anim 2006; 40:153-71.

21 York M, Scudamore C, Brady S, et al. Characterization of troponin responses in isoproterenol-induced cardiac injury in the hanover wistar rat. Toxicol Pathol 2007;35:606-17

22 O'Brien PJ. Cardiac troponin is the most effective translational safety biomarker for myocardial injury in cardiotoxicity. Toxicol 2008;245:206-18.

23 Potter LR, Yoder AR, Flora DR, et al. Natriuretic peptides: their structures, receptors, physiologic functions and therapeutic applications. Handb Exp Pharmacol 2009;191:341-66.

24 De Bold A. Atrial natriuretic factor: a hormone produced by the heart. Science 1985:230:767-70.

25 Aquaro GD, Gabutti A, Meini M, et al. Silent myocardial damage in cocaine addicts. Heart 2011;97:2056-62.

26 McDonagh TA, Holmer S, Raymond I, et al. NT proBNP and the diagnosis of heart failure: a pooled analysis of three European epidemiological studies. Eur J Heart Fail 2004:6:269-73.

27 Briscoe RJ, Baird TJ, Lerner MR, et al. Cocaine-induced cardiovascular responses in rats during acute ethanol withdrawal. Alcohol 1999;19:131-7.

28 Laizure SC, Parker RB. Pharmacodynamic evaluation of the cardiovascular effects after the coadministration of cocaine and ethanol. Drug Metab Dispos 2009;37:310-14. 